\title{
Resources and dynamics of halophytes in agricultural and industrial landscapes of the western part of Kujawy, Central Poland
}

\author{
Wiesława Karasińska ${ }^{1}$, Andrzej Nienartowicz ${ }^{1}$, Mieczysław Kunz ${ }^{2}$, \\ Dariusz Kamiński ${ }^{1, *}$, Agnieszka Piernik $^{1}$
}

\footnotetext{
${ }^{1}$ Nicolaus Copernicus University, Faculty of Biological and Veterinary Sciences, 87-100 Toruń, Lwowska Str 1, Poland

${ }^{2}$ Nicolaus Copernicus University, Faculty of Earth Sciences and Spatial Management, 87-100 Toruń, Lwowska Str 1, Poland *corresponding author e-mail: daro@umk.pl
}

Received: 19 March 2021 / Accepted: 9 June 2021

This article is dedicated to the memory of tireless researcher of saline vegetation in Kujawy Professor Jadwiga Wilkoń-Michalska (1921-2005)

\begin{abstract}
This paper presents the status and comparison of the halophytic flora on two research plots in the Upper Noteć catchment, distinguished by the intensity of human activity and the type of landscape: 1 - Lake Gopło (G) and 2 - the area located by the Noteć Canal $(\mathrm{N})$ in the western part of the Kujawy region. Fishery on the twelfth largest lake in Poland and agriculture are the main forms of economy in the former plot. A significant part of this plot is a Natura 2000 site, legally protected in compliance with the EU directives. The development of halophytes, mainly facultative ones, in the $\mathrm{G}$ plot is conditioned by natural factors, i.e. the inflow of saline groundwater. In the $\mathrm{N}$ plot, the agricultural landscape was transformed into the industrial and urbanized landscape following the years of development of two soda factories and the municipal and housing infrastructure of the nearby town of Inowrocław. Strong human impact led to the fact that already several decades ago this plot was classified as one of the most ecologically endangered areas in Poland. The abundance of halophytes in the N plot, including many obligatory ones, is related to the geomorphology of the area and the associated pattern of salt deposit leaching, as well as brine exploitation and soda industry. The species composition and population resources of individual halophyte species at 65 sites on the $G$ plot and 90 sites on the $\mathrm{N}$ plot were compared using numerical classification methods. The distribution of the sites and their species richness are presented on the maps of the study area. The results of our analysis were compared with the results of observations made by other authors in the same area at different times. Based on the comparative analysis, we have arrived at conclusions regarding the protection of halophytes and the anticipated effects of technological changes in agriculture, salt and soda industry, as well as spatial management. We believe that the data provided in the tables and the resulting maps will constitute reference points for assessing the effectiveness of undertaken conservation recommendations and the correctness of scenarios formulated by different authors for the development of natural systems in the study area.
\end{abstract}

Keywords: inland salt marshes, flora, species richness, population resources, active protection, Natura 2000 site, numerical taxonomy, mapping, soil salinity, temporal changes. 


\section{Introduction}

The European inland salt marshes are endangered; therefore, they are legally protected under the Natura 2000 network (Directive 92/43/EEC of May 21, 1992). However, halophilous vegetation at inland sites of Central Europe has long been included in the nature reserve conservation, as it is an unique vegetation in humid climate conditions (WilkońMichalska 1962, 1970, 1986, Trzcińska-Tacik 1988, Bank and Spitzenberg 2001, Pusch 2007). Apart from natural sites of halophytes, there are also industrial sites connected with the development of soda, potassium and salt industry (Wilkon'Michalska 1957, 1963, Westhus et al. 1997, Schmeisky and Podlacha 2000, Piernik 2003a, 2003b, van Elsen 2005). They are located in the vicinity of salt mine dumps, next to waste ponds of the soda factory, along leaky brine pipelines and waste collectors. They can serve as species pool for natural saline habitats. That is why, they are worth to be monitored together with natural sites especially in some regions where both natural and industrial sites coexist.

The Kujawy region, located between the Vistula and the Noteć Górna rivers, is one of the main areas where halophytes occur in Poland. The presence of this group of plants is determined by natural factors, i.e. the presence of saline springs, as well as anthropogenic factors, which mainly include the exploitation of salt and brine deposits. As a result of intensive human activity, especially in urban and industrial areas, the range of halophytes and halophytic communities in Kujawy has been changing rapidly. Staff of the Faculty of Biology and Earth Sciences of the Nicolaus Copernicus University in Toruń, established in 1945, began to monitor these changes over sixty years ago, i.e. a few years after the University was founded.

The whole region of so-called Black Kujawy (Kujawy Czarne as defined by Matuszkiewicz 1993) remains within the area of interest of florists and ecologists from our University, however, a few selected sites have been subjected to particularly thorough and frequent observations and measurements. These are usually the areas where observations were carried out in the 19th and early 20th centuries by Prussian, German, and Polish florists. The research undertaken by our University in the early 1950s is therefore conducted relative to those earlier observations.

One of the first study sites for Torun botanists was the area located on the Noteć River and the Noteć Canal in the vicinity of Mątwy and Janikowo. The research undertaken in Mątwy referred to numerous floristic studies conducted at the turn of the 19th and 20th centuries (Rostafiński, 1871; Spribille, 1889; Abromeit et al., 1898-1940; Bock, 1908, Liebetanz, 1925; Wodziczko et al., 1938). The abundance of halophytes in this region is related to the development of salt and soda industry as well as spa treatments that have started here at the end of the 19th century. The floristic and ecological research carried out by the University of Torun in the area of the latter, i.e. the town of Janikowo, was prompted by the construction of Janikowskie Zakłady Sodowe (soda plants), which began in the late 1950s, and by the expected strong environmental impact of the expanded industrial infrastructure. In the period preceding the construction, no sites with halophytes were recorded in the area of Janikowo.

The area of Lake Gopło in the western part of Kujawy, located south-east of Mątwy and Janikowo, has also become an important study area for botanists from the University of Torun. Intensive floristic research in this historically and environmentally interesting area was inspired by the upcoming celebrations of the Millennium of the Polish State in 1966. The results of these studies were the basis for establishing the "Nadgoplański Park Tysiąclecia" (Gopło Millennium Park) nature reserve in 1967.

Professor Jadwiga Wilkoń-Michalska was the person who provided most information on the halophytic flora in the area of Lake Gopło and the Noteć Canal. The floristic data were presented mainly in the study "Halofity Kujaw" (Halophytes of Kujawy) published in 1963. In addition to detailed descriptions of the halophytic flora and vegetation and the prevailing ecological conditions, the work contains maps with marked localities of individual halophytic species. More than 30 years later, information on changes in the halophytic flora in these regions was provided by research carried out under the KBN (State Committee for Scientific Research) grant supervised by Prof. Wilkoń-Michalska and several doctoral theses completed and promoted by her pupils (Nienartowicz \& Wilkoń-Michalska, 1993a, 1993b; Wilkoń-Michalska et al., 1997; Piernik, 2000; Nienartowicz \& Warot, 2001; Warot et al., 2001; Warot, 2003; Karasińska, 2004; Nienartowicz \& Piernik, 2004; Piernik, 2012; Twerd, 2012). Floristic lists and descriptions of vegetation obtained in these studies were presented in a number of papers. However, these data were not presented in the form of cartographic materials. The present work is intended to fill this gap.

The objective of this study is to present the flora of halophytes in the area of Lake Gopło and the Noteć Canal as of the end of the 20th century and to answer two questions: 1) How has the flora of halophytes changed in these regions compared to the earlier states and some of the subsequent ones? and 2) How large are the differences in the flora of halophytes occurring in the complex of extensively used meadows at Lake Gopło and at the sites near the soda plants at the Noteć Canal?

We are convinced that the cartographic materials included in the paper may serve a reference for the current observations and future research on the occurrence of halophytes in the western part of Kujawy. 


\section{Study area}

Two study plots were included in the research. They are referred to in the text as Gopło and Noteć and are marked with symbols $\mathrm{G}$ and $\mathrm{N}$, respectively. Figure 1 shows their location on the map of Poland. According to the current administrative division of Poland, this part of Kujawy and both study plots are located in the western part of the Kuyavian-Pomeranian Province. Whereas, according to the physical and geographical regionalization of Poland by Kondracki (2000), the study area belongs to the macroregion of the Great Poland Lakeland (315.5) and includes two mesoregions: the Inowrocław Plain (315.55) and the Kujawy Lakeland (315.57).

In geobotanical terms, the area is part of the Pas Wielkich Dolin (Great Valleys Belt) subdivision, the Great Poland-Kujawy region, and the Kujawy district (Szafer \& Zarzycki, 1972). In his study “Krajobrazy roślinne i regiony geobotaniczne Polski" [Vegetation landscape and geobotanical regions of Poland], Matuszkiewicz (1993) classified this area as part of the so-called Kujawy Czarne district within the Wielkopolska-Kujawy subregion.

\subsection{Study plot Gopło}

The glacial trough of Lake Gopło (ribbon lake) is the main geomorphological form on the G plot. It is about $40 \mathrm{~km}$ long and runs meridionally. Lake Gopło is a flow-through system through which flows the Noteć River - the seventh longest river in Poland. It plays a major role in shaping the hydrological regime of Lake Gopło. In addition, a number of canals and ditches flow into the lake. The lake basin has an elongated shape with the NNW-SSE course and consists of two reservoirs. The main basin is formed by a glacial trough with a considerable diversity of the bottom relief and a length of $25 \mathrm{~km}$. On the western side, the trough section joins the

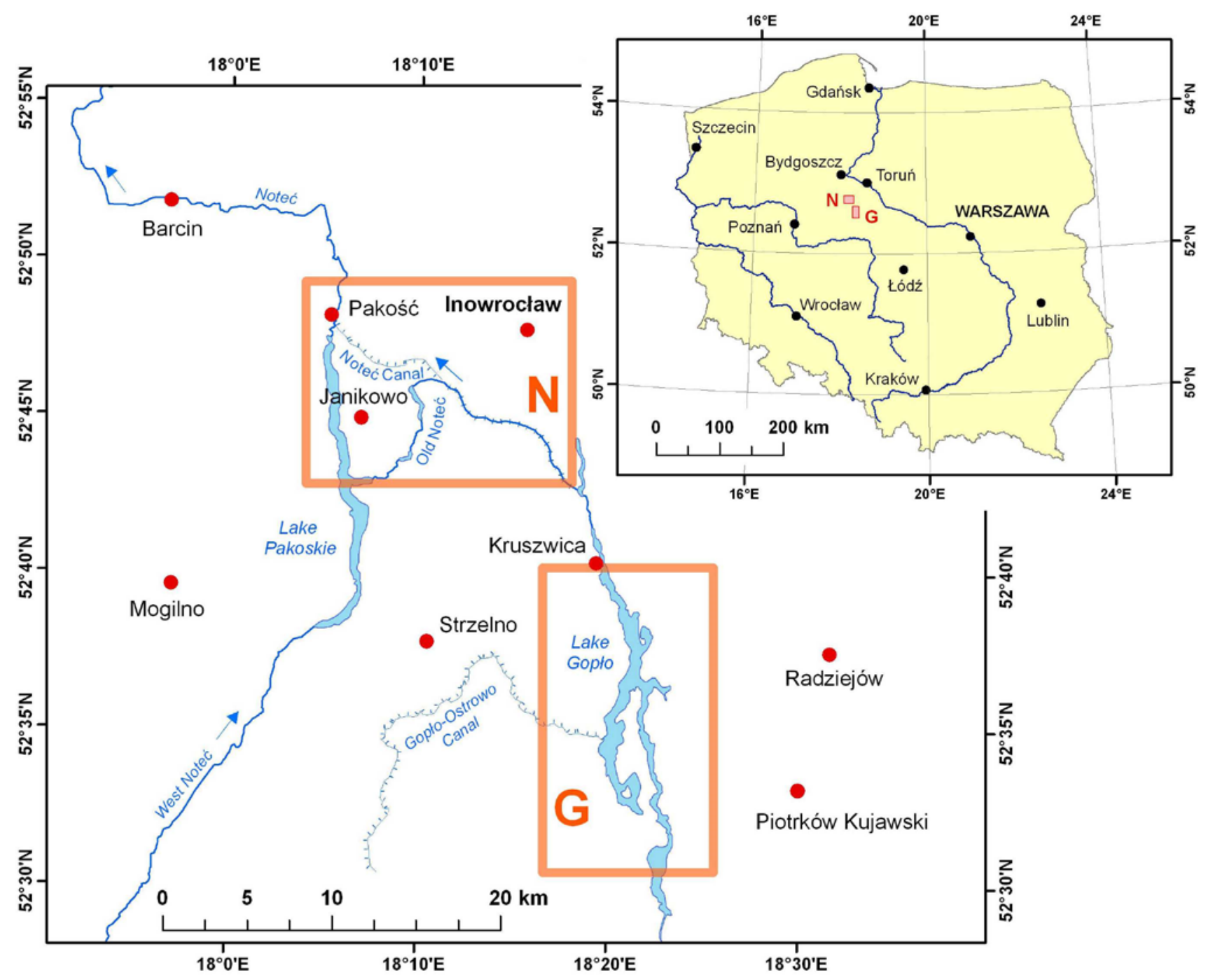

Figure 1. Location of the study plots $\mathrm{G}$ and $\mathrm{N}$ in Poland 
cove section of the lake, where the depth increases towards the north (Marszelewski \& Skowron, 2011). The two parts of the lake are separated by the Potrzymiech Peninsula. The surface area of the lake is $2,121.5$ ha, the capacity is 78.497 million $\mathrm{m}^{3}$, the average depth is $3.6 \mathrm{~m}$ and the maximum depth is $16.6 \mathrm{~m}$ (Choiński, 2006).

Wetlands are an important element of the study area. They occur in many places in the shore zone of the lake, especially on the Potrzymiech Peninsula. They were formed as a result of water level lowering in the lake. The major changes in the original hydrographic network of the Noteć river basin occurred as a result of hydrotechnical works carried out in the late 18th century (Mastyński \& Rogiński, 1964; Niewiarowski, 2000; Dorożyński \& Skowron, 2002).

Due to the natural and historical values of this area, the existing nature reserve was transformed into the Gopło Millennium Landscape Park in 1992. Natura 2000 Special Protection Area PLB04004 Ostoja Nadgoplańska (Regulation of the Minister of the Environment, 2004) was established in the area on 21 July 2004 and Special Area of Conservation PLH04007 Jezioro Gopło (Commission Decision, 2008) was created on 12 December 2008.

The area around Lake Gopło, included in the Natura 2000 network, has a very long history of residential development. Long-lasting human presence and farming resulted in significant transformations of the vegetation, manifested by the dominance of segetal and ruderal communities characteristic of the agricultural landscape, as well as the distortion of forest and meadow communities. Despite the increasing anthropopressure, a number of valuable natural habitats and localities of rare plant species have been preserved within this refuge. Some of them have emerged and survived to this day precisely because of human activity. These include, in particular, communities of humid meadows and meadows with varying moisture conditions developed on lacustrine sediments following the lowering of the water level in Lake Gopło in the 19th century. Apart from Molinia and Cnidium meadows and species-rich meadows of the Calthion alliance, subhalophytic communities of the Potentillo-Festucetum association with facultative halophytes are found in the area, as well as very rare in the discussed area phytocoenoses of Triglochino-Glaucetum maritimae (Hulisz et al., 2017a). The flora of the Ostoja Nadgoplańska and Jezioro Gopło Natura 2000 sites is relatively rich. According to Chmiel (1999), 867 species of vascular plants occur here, which accounts for almost $30 \%$ of the Polish flora.

\subsection{Study plot Noteć Canal}

For over 150 years, the $\mathrm{N}$ surface has been subject to much stronger anthropopressure, related to the development of salt and soda industry. The development of these industries took place, among others, after Aleksander Humboldt's research conducted in Inowrocław before 1835, which indicated the existence of rock salt deposits, and the later (1871) discovery of brine deposits with a concentration of $12 \%$ in the "Ost" borehole, as well as rich, exploitable salt deposits after the drilling of the "Bast" and "Piekle" boreholes (Sikorski, 1988).

The main watercourse on the $\mathrm{N}$ plot is the Noteć Canal. It is a waterway covering the canalized course of the Noteć River, stretching from Lake Szarlej to the town of Pakość. The canal was built over 100 years ago and is a navigation shortcut allowing one to bypass the nearby large Pakoskie Lake. The length of the canal is approximately $19 \mathrm{~km}$. Two large chemical plants are located by the Noteć Canal, which mainly produce soda, but also many other products based on brine imported through pipelines. These factories operate in Mątwy, which is today a district of the town of Inowrocław, and in Janikowo. The distance between the two plants along the canal is approximately $12 \mathrm{~km}$.

In Mątwy, the production of soda ash was undertaken by Chemische Fabrik Montwy, Robert Suermondt Co. already in 1882. In the period between World War I and World War II, the production of soda was developed here by the "Solvay" plant, and since 1945 by Inowrocławskie Zakłady Chemiczne im. Bolesława Rumińskiego (Bolesław Rumiński Chemical Plants in Inowrocław). In 1991, the company was commercialized and transformed into a joint stock company of the State Treasury IZCh "Soda Mątwy” S.A.

The production of soda in Janikowo began in 1957 when the construction of Janikowskie Zakłady Sodowe (Janikowo Soda Plant) was completed in cooperation with the Soviet Union. The commercialization of this enterprise was carried out in 1992 by transforming it into a joint-stock company of the State Treasury, Zakład “Janikosoda” S.A. In August 1996, the majority stake of Zakład "Janikosoda" S.A and IZCh "Soda-Mątwy" S.A. was purchased from the State Treasury by Ciech S.A., which created a holding of soda plants. In 2007, both soda plants in Inowrocław-Mątwy and Janikowo were merged into one company, Ciech Soda Polska S.A.

Apart from the Noteć Canal and the riverbed of the Stara Noteć River, which flows through Lake Węgiereckie and Lake Pakoskie, the study area is intersected by ditches draining saline sewage from the saltworks operating in the western part of Inowrocław since 1873 (initially as "Saline", in the interwar period as "Żupa solna", and currently as "Solino"; after Grabarek, 1974) and from a health resort, the first pavilions of which were built in 1876-1878 (Papierowski, 1963). Wastewater treatment plants are located near the post-production waste settling tanks of both soda plants. Substrates for the salt and soda industry as well as for the health resort are supplied through pipelines by the "Góra" salt mine, which, together with the "Mogilno" mine, is 
subordinate to Inowrocławskie Kopalnie Soli (Inowrocław Salt Mines) "Solino" S.A.

The area of Inowrocław and Janikowo, for a long time strongly transformed by technical infrastructure and intensively exploited economically, in the 1980s and the 1990s was classified as one of the 27 environmentally hazardous areas in Poland (Kozłowski et al., 1989). In both plants, the production of soda and other by-products was accompanied by the formation of huge amounts of lime sludge, which was discharged into expanding settling ponds known as "white seas". At the beginning of the 1990s, soda plants were on the list of 80 most environmentally harmful plants in Poland. The environmental conditions improved in the second half of the 1990s, when soda plants obtained ISO 9001 certificates in 1996 and ISO 14001 certificates in 1999.

Despite attempts to reduce the impact of the industry on the environment, the area around Inowrocław and Janikowo remained an area of inland salt marshes. According to Wilkon'-Michalska (1963), the density of halophytes in this area is related to the geomorphology of the area and the related pattern of salt deposit leaching, as well as the exploitation of brine and the soda industry.

\section{Methods}

Information on the distribution of halophytes on the $G$ plot come from the doctoral dissertation by L. Warot (2003) as part of the KBN grant. The study area in this work was a section of the Potrzymiech Peninsula from the town of Ostrówek towards the north, and the shores of the northern part of Lake Gopło. Geographical coordinates of 65 halophyte sites in this area, determined with the use of a GPS receiver, were included in the tables. They were used as a basis for marking the sites on the map prepared by us as part of this study.

Data on the distribution of halophytes on the $\mathrm{N}$ plot come from the study by Karasińska (2003). The study presents a description of 285 halophyte sites surveyed in 1993-1998 and located in the area presented on the map sheet 1:25,000 Inowrocław in the 1965 coordinate system. This study includes only 90 sites located on both sides of the Noteć Canal within a distance of up to $800 \mathrm{~m}$ from its banks. All these sites were recorded in 1995-1998.

Of the various characteristics of the sites reported in the study, our analysis took into account the location of the sites, as well as species composition and population resources of species at a given site. A site was defined as an area representing a developmental stage of a halophytic meadow, clearly distinguishable in complexes of non-halophytic meadows at Lake Gopło and the Noteć River and segetal and ruderal communities occurring here, and not bordering on other vegetation patches with halophytes. Population resources of the species were assessed on a 5-point scale: I - 1-10 aboveground shoots; II - 11-50 shoots; III - 51-100 shoots; IV - 101-1,000 shoots; V - over 1,000 aboveground shoots at a site.

The species composition and abundance of species expressed in the above scale served as characteristics in the comparisons of 155 halophyte sites using numerical taxonomy methods. Classification of the sites and species was performed using MVSP (Kovach, 1993) and TWINSPAN (Hill, 1979) programs. In the numerical classification, the Minimum Variance method was used from the former program. Hierarchical divisive classification with the TWINSPAN program was performed using default parameters and the detrending procedure.

The halophyte flora of both plots from 1998 was compared with the earlier and later states using data of other authors found in the ecological literature. To present the results of some comparisons, additional maps of the distribution of halophyte species were prepared. In the case of the G plot, the cartographic data from the study by Hulisz et al. (2017a) were used as a reference. For the N plot located at the Noteć Canal, the comparisons were made with reference to the data contained in the work by Wilkoń-Michalska (1957) To increase the accuracy of comparisons, our maps include the same content as those showing the distribution of halophyte species 40 years ago.

The names of plant species in our analysis are given according to Mirek et al. (2002) and WFO (2021).

\section{Results}

Eighteen species of halophytes, including six obligatory and 12 facultative ones, were recorded on both plots (Table 1). Two obligatory species, i.e. Atriplex prostrata and Glaux maritima, were found on plot $\mathrm{G}$, but they occurred with low frequency. They were recorded only at two sites and one site, respectively. Six obligatory halophytes were recorded on the N plot: Spergularia marina, Salicornia europaea, Triglochin maritima and Aster tripolium, in addition to the two above-mentioned species. All of them reached quite high frequencies.

Of all the considered species on plot $G$, i.e. on the Potrzymiech Peninsula and around Lake Gopło, the highest frequency was recorded for the facultative species, i.e. Trifolium fragiferum, Schoenoplectus tabernaenontani, Melilotus dentatus and Festuca arundinacea. All species of halophytes that reached high frequency on this plot were characterized by high variability of the population resources (Table 1).

The highest frequency on the $\mathrm{N}$ plot was recorded for the facultative halophyte Puccinellia distans and two obligatory halophytes - Atriplex prostrata and Spergularia marina. The 
Table 1. The number of sites and population resources of halophytes near Lake Gopło (G) and the Channel Noteć (N) according to Warot (2003) and Karasińska (2003)

\begin{tabular}{|c|c|c|c|c|c|}
\hline \multirow[t]{2}{*}{ No. } & \multirow[t]{2}{*}{ Species } & \multicolumn{2}{|c|}{$\begin{array}{l}\text { Area G - Gopło Lake } \\
\quad \mathrm{n}=65\end{array}$} & \multicolumn{2}{|c|}{$\begin{array}{c}\text { Area N - Noteć Canal } \\
n=90\end{array}$} \\
\hline & & Number of sites & $\begin{array}{c}\text { Population } \\
\text { resources }\end{array}$ & Number of sites & $\begin{array}{c}\text { Population } \\
\text { resources }\end{array}$ \\
\hline 1. & ${ }^{*}$ Spergularia marina (L.) Besser & - & - & 31 & III-V \\
\hline 2. & ${ }^{*}$ Salicornia europaea L. & - & - & 22 & IV-V \\
\hline 3. & ${ }^{*}$ Triglochin maritima $\mathrm{L}$. & - & - & 21 & III-V \\
\hline 4. & $\begin{array}{l}{ }^{*} \text { Aster tripolium } \mathrm{L} .=\text { Tripolium pannonicum } \\
\text { subsp. tripolium }(\mathrm{L} .) \text { Greuter }\end{array}$ & - & - & 15 & $\mathrm{I}-\mathrm{V}$ \\
\hline 5. & ${ }^{*}$ Atriplex prostrata Boucher ex DC & 2 & I & 42 & II-V \\
\hline 6. & $\begin{array}{l}{ }^{*} \text { Glaux maritima L. }=\text { Lysimachia maritima }(\mathrm{L} .) \\
\text { Galasso, Banfi \& Soldano }\end{array}$ & 1 & $\mathrm{~V}$ & 6 & IV-V \\
\hline 7. & Puccinellia distans (Jacq.) Parl. & 2 & $\mathrm{~V}$ & 68 & II-V \\
\hline 8. & Trifolium fragiferum $\mathrm{L}$. & 31 & $\mathrm{I}-\mathrm{V}$ & 24 & $\mathrm{I}-\mathrm{V}$ \\
\hline 9. & $\begin{array}{l}\text { Schoenoplectus tabernaemontani (C.C. Gmel.) } \\
\text { Palla }\end{array}$ & 24 & II-V & 14 & III-V \\
\hline 10. & Bolboschoenus maritimus (L.) Palla & 16 & II-V & 19 & III-V \\
\hline 11. & Melilotus dentatus (Waldst. \& Kit.) Pers. & 21 & $\mathrm{I}-\mathrm{V}$ & 1 & III \\
\hline 12. & Festuca arundinacea Schreb. & 20 & $\mathrm{I}-\mathrm{V}$ & 10 & III-V \\
\hline 13. & Lotus tenuis Waldst. \& Kit. & 12 & II-V & 4 & III-V \\
\hline 14. & Carex distans $\mathrm{L}$. & 12 & $\mathrm{I}-\mathrm{V}$ & 4 & II-IV \\
\hline 15. & $\begin{array}{l}\text { Tetragonolobus maritimus (L.) Roth }=\text { Lotus } \\
\text { maritimus L. }\end{array}$ & 3 & IV-V & 4 & III-V \\
\hline 16. & Juncus ranarius Songeon \& E.P. Perrier & 4 & I-IV & - & - \\
\hline 17. & Centaurium pulchellum (Sw.) Druce & 2 & I & - & - \\
\hline 18. & Althaea officinalis L. & - & - & 1 & III \\
\hline
\end{tabular}

*obligatory halophytes.

species occurring with high frequency on this plot were usually characterized by high variability of the population resources, often in the range of $\mathrm{I}-\mathrm{V}$. The exception was Salicornia europaea, a halophyte occurring in the most saline conditions. Its population resources at all 22 sites were significant and showed little variability in the IV-V range.

On plot G, from one to seven species of halophytes were found at individual sites, and on plot $\mathrm{N}$ - from 1 to 8 species. On both plots, the largest number of sites contained only one species, i.e. 26 and 25 sites, respectively. There were six sites with the largest number of species (5-7) on plot $G$ and 22 sites on plot N. On both plots, two sites with the largest number of species, i.e. seven on plot $\mathrm{G}$ and eight on plot $\mathrm{N}$, were recorded. The number of sites according to the number of species on both plots is presented in Table 2.

The spatial analysis showed that halophytes on the $G$ plot occur mainly on the Potrzymiech Peninsula and on the shores of the northern part of Lake Gopło. Four out of six sites with the largest number of species (class 5-7) were also located on the peninsula. Only one site was located on the northern shore of the lake near the village of Rzeptowo and one site on the south-eastern shore of the lake near the village of Złotowo (Fig. 2). On the Potrzymiech Peninsula and on the northern
Table 2. The number of sites in relation to the number of species on $\mathrm{G}$ and $\mathrm{N}$ plots

\begin{tabular}{|c|c|c|}
\hline \multirow{2}{*}{$\begin{array}{c}\text { Number of } \\
\text { halophytic species } \\
\text { in site }\end{array}$} & $\begin{array}{c}|c| \\
\text { Gopło } \\
\text { G }\end{array}$ & $\begin{array}{c}\text { Noteć Canal } \\
\text { N }\end{array}$ \\
\hline 1 & 26 & 25 \\
\hline 2 & 17 & 16 \\
\hline 3 & 8 & 13 \\
\hline 4 & 8 & 12 \\
\hline 5 & 4 & 10 \\
\hline 6 & 0 & 8 \\
\hline 7 & 2 & 4 \\
\hline 8 & 0 & 2 \\
\hline Number of sites & 65 & 90 \\
\hline
\end{tabular}

shore of Lake Gopło, species with the highest abundance on plot G, such as Trifolium fragiferum and Bolboschoenus maritimus, developed the highest population resources in these locations. The Potrzymiech Peninsula features also the only site of the obligatory halophyte Glaux maritima and the facultative halophyte Puccinellia distans, which is much less frequent on the G plot than on the N plot (Fig. 3). 


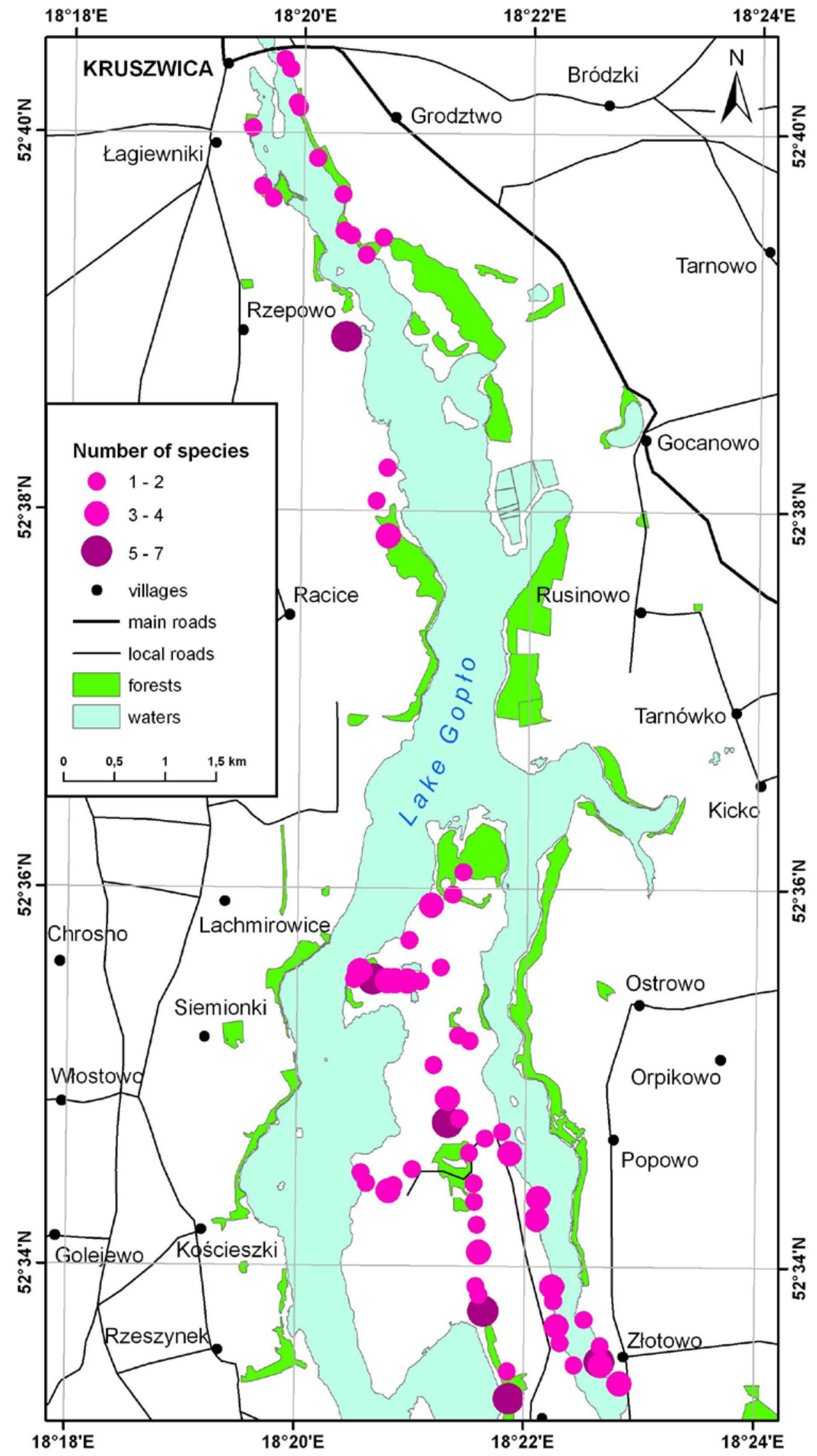

Figure 2. The number of halophyte species at 65 sites on plot $\mathrm{G}$ 


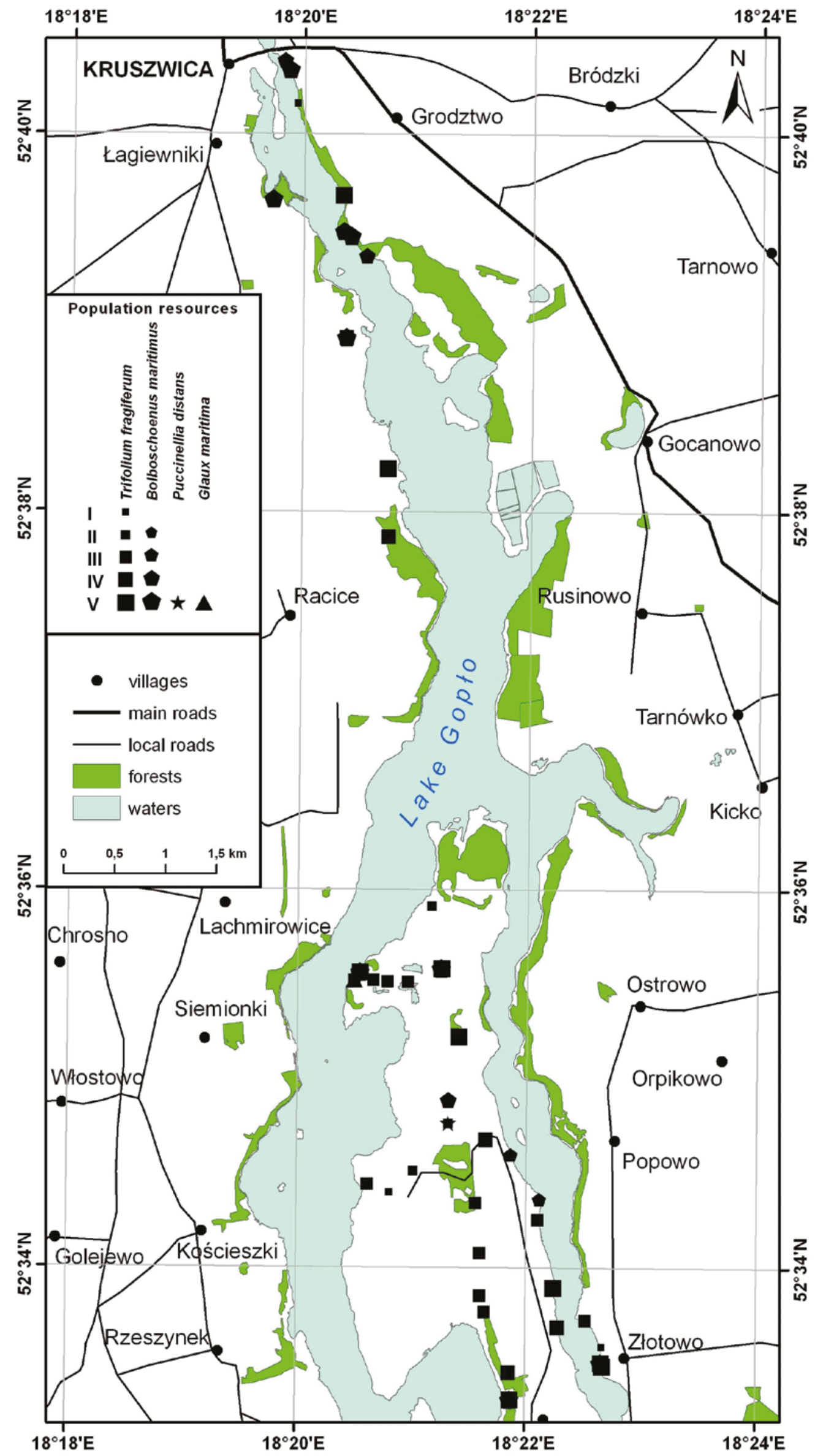

Figure 3. Distribution and population resources of some halophytic species on plot $\mathrm{G}$ 
On the $\mathrm{N}$ plot, the highest density of halophyte sites occurred near both soda plants, downstream of the Noteć Canal (Fig. 4). Sites with the largest number of species, including obligatory halophytes, were also observed in these locations. The population resources of the halophytes occurring here were usually very high. More localities were recorded near Janikowskie Zakłady Sodowe than near Inowrocławskie Zakłady Chemiczne in Mątwy. Several sites occurred also upstream of the Noteć Canal, starting from the soda factories, i.e. near the villages of Tupadły, Przedbojowice and Janowice. These sites usually contained few species of halophytes and their population resources were small.

The numerical classification of the halophyte species on both study plots showed the presence of three groups in the set of 18 species (Fig. 5). The first group consists of three obligatory halophytes - Spergularia marina, Salicornia europaea and Atriplex prostrata, and the facultative halophyte Puccinellia distans. In the study area, they occur mainly on humid and most saline soils. The second group consists of three facultative species - Trifolium fragiferum, Bolboschoenus maritimus and Schoenoplectus tabernaemontani, occurring on wet soils, often with stagnant water, at low salinity on the substrate. The third group consists of 12 species, including three obligatory halophytes Aster tripolium, Glaux maritima and Triglochin maritima, the latter being quite different from the others, and nine facultative halophytes. All these species are found on moderately moist and saline soils.

The numerical classification performed with the TWINSPAN program on the whole set of 155 sites showed very clear differences between $\mathrm{G}$ and $\mathrm{N}$ plots. The first level of the dichotomous division separated the only site with the facultative halophyte Centaurium pulchellum located at Lake

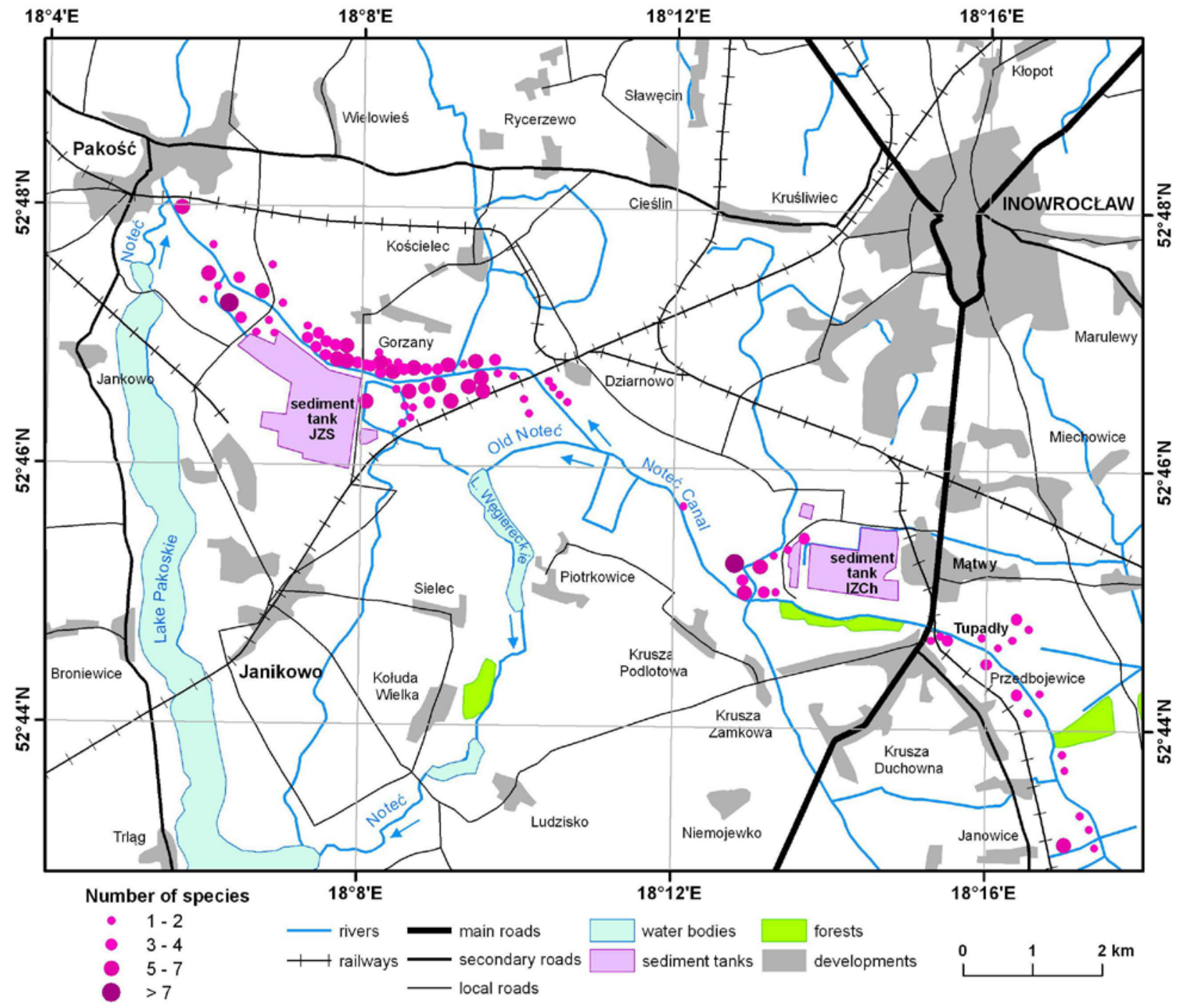

Figure 4. Distribution and species richness of halophytes on plot $\mathrm{N}$ 


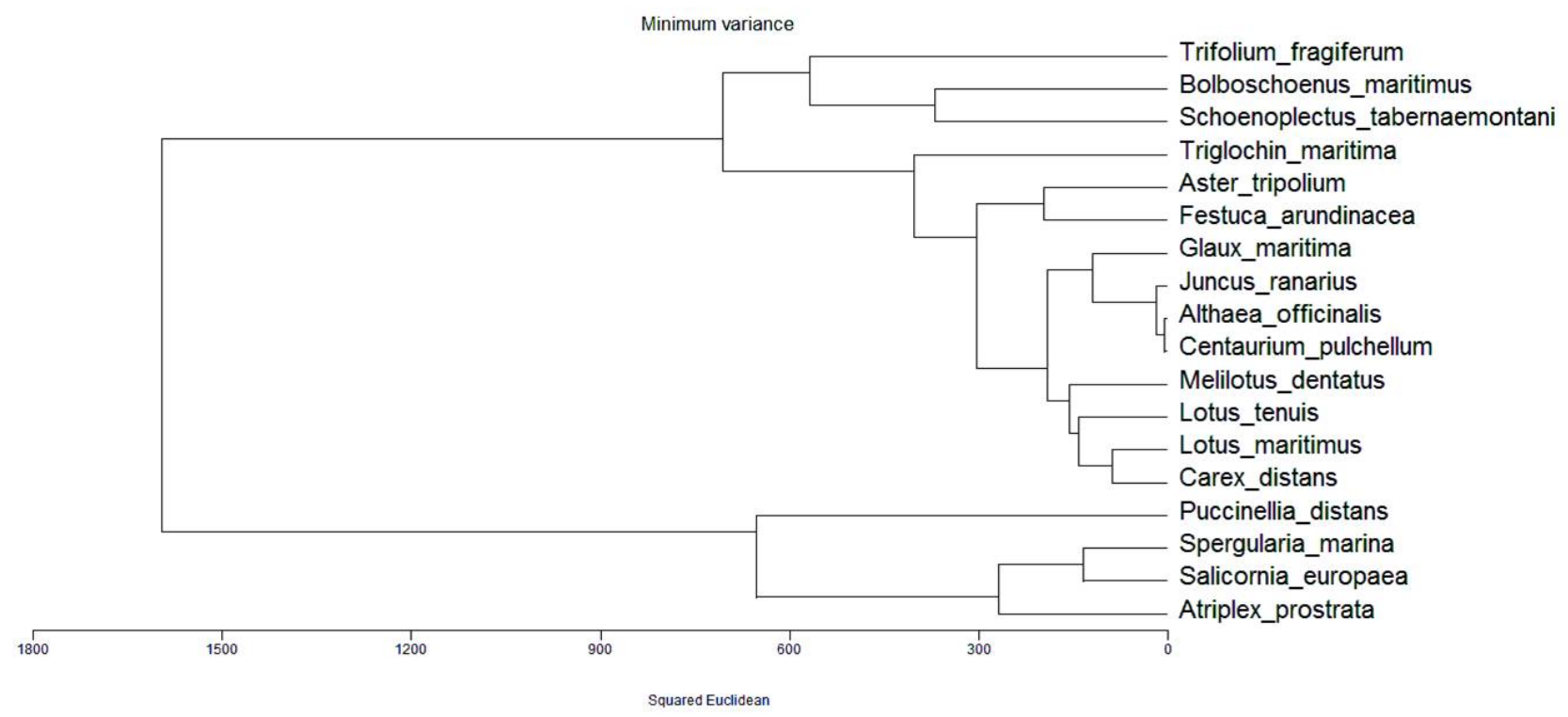

Figure 5. Classification of 18 halophytic species according to their presence and population resources at 155 sites on plots $\mathrm{G}$ and $\mathrm{N}$

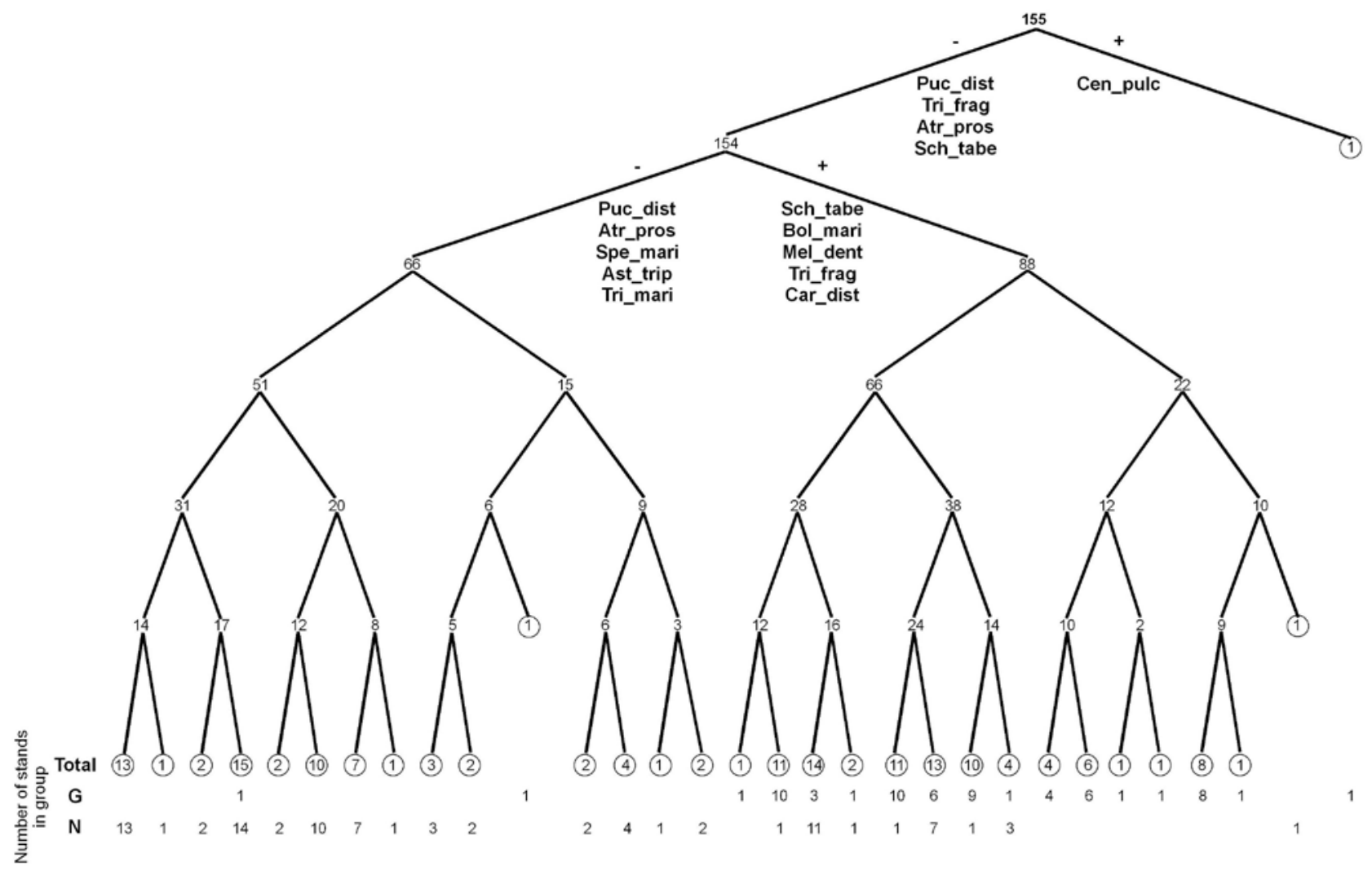

Figure 6. TWINSPAN classification of 155 sites located on plots $\mathrm{G}$ and N according to the presence of halophytic species and their population resources 
Gopło (Fig. 6). Three facultative species and one obligatory species, Atriplex prostrata, were indicated here as negative indicators. At the second level of the division, the group of 154 sites was divided into a negative group of 66 sites and a positive group of 88 sites. The identifiers of the negative group were the obligatory halophytes, while the facultative halophytes were the identifiers of the positive group. This division corresponds to the division into $\mathrm{N}$ and $\mathrm{G}$ plots. The negative group comprises 64 sites from the Noteć Canal and only 2 sites from Lake Gopło. The positive group is dominated by 62 sites from plot G, but it also includes 26 sites from the Noteć Canal, located mainly in places with less saline soils, in the section between the villages of Tupadły and Janowice.

\section{Discussion}

Comparisons of our results with the literature data indicate that in the past there were more sites with obligatory halophytes in the area of Lake Gopło. They were recorded at eight sites in total, while in the studies discussed in our paper there were three sites, including two sites with Atriplex prostrata and one site with Glaux maritima.

According to our data, both sites of Atriplex prostrata (a species not mentioned in the synoptic phytosociological tables or on the map by Hulisz et al., 2017a) were located in the northern part of the Potrzymiech Peninsula, thus relatively far from the lake shore where the facultative halophyte Trifolium fragiferum was frequently noted (Fig. 3). Glaux maritima, on the other hand, occurred in the past at four localities, on the meadow in the village of Łagiewniki near the town of Kruszwica, along the eastern shore of a small lake in the village of Gocanowo, located approx. $1 \mathrm{~km}$ east of Lake Gopło, in the meadow north of the village of Ostrówek on the Potrzymiech Peninsula and in the meadow in the northwestern part of this Peninsula (called Potrzymiech Kopiński; Fig. 7). In all locations, the population was small and did not exceed several dozen shoots (class II or III), forming small clusters among the meadow vegetation (Załuski 1992, 1995). In Gocanów, Glaux maritima was the most abundant species, which grew on the devastated shore of a small lake (Chmiel, 1987).

According to the literature data, Triglochin maritima occurred at three sites (Fig. 7) on the Potrzymiech Peninsula: on the eastern shore in its northern part; near the village of Ostrówek in the central part, and below the base of the Potrzymiech Peninsula in the village of Łuszczewo, near the farm buildings of the former palace complex. According to the personal communication by P. Stopiński (after Hulisz et al., 2017a), Triglochin maritima was also present at another (fourth) site located in the meadow south-east of Łuszczewo.
At any of the known historical sites, its abundance did not exceed several dozen individuals.

Based on the data included in our analysis, Glaux maritima occurred only in the north-western part of the Potrzymiech Peninsula (in Potrzymiech Kopiński), i.e. near one of the eight obligatory halophyte sites mentioned above (Figs 3 and 7). However, there is no evidence to conclude that Glaux maritima occurs continuously, i.e. uninterruptedly, in this part of the Potrzymiech Peninsula over the entire time horizon considered in this comparison. On the other hand, the lack of information in our analysis about the only Triglochin maritima site mentioned in the 2017 study results from the fact that the vicinity of the village of Łuszczewo is located outside the southern boundary of plot $G$ and this area was not included in our study.

The map with the distribution of halophytes in the district of Inowrocław, prepared by Wilkon-Michalska (1963) based on the literature shows yet another locality of Triglochin maritima. It was marked on the eastern shore of Lake Gopło near the village of Grodztwo. On the other hand, the presence of the obligatory halophyte Glaux maritima, the second characteristic species of the TriglochinoGlaucetum maritimae association next to Triglochin matitima, was indicated by Wilkon-Michalska (1963) on the map of halophyte sites in the same area, compiled on the basis of her own research. The site of this species was marked below the outlet of the Bachorze Canal into Lake Gopło. She also marked the presence of five facultative halophytes on the map (out of 12 identified in our analysis): Puccinellia distans, Trifolium fragiferum, Lotus tenuis, Bolboschoenus maritimus and Schoenoplectus tabernaemontani growing in the northern part of Lake Gopło.

There are no data that would unequivocally indicate that the historical sites of obligatory halophytes presented on the map (Fig. 8) existed in 2007, which is when the area of Lake Gopło was proposed for inclusion in the Natura 2000 network. In the case of the Gocanów site, the last information on the occurrence of Glaux maritima come from 1992 (Załuski, 1992). Nor was Glaux maritima found in Gocanów in 2008, when monitoring of habitat 1340 began there. At that time, only two facultative halophytes - Trifolium fragiferum and Lotus tenuis - occurred there. Glaux maritima was not observed at this site five years later, i.e. in 2013, when the protection policy for the Natura 2000 area PLH040007 Gopło Lake was implemented. On the other hand, the disappearance of Glaux maritima at the Potrzymiech Kopiński site was noted in 1999 (Załuski, 1999).

At the sites in Gocanów and Potrzymiech Kopiński, obligatory halophytes were also not found during the studies carried out in 2017 (Hulisz et al., 2017a). At the former site, only facultative halophytes were present: Festuca arundinacea, Lotus tenuis and Trifolium fragiferum, while in Potrzymiech 


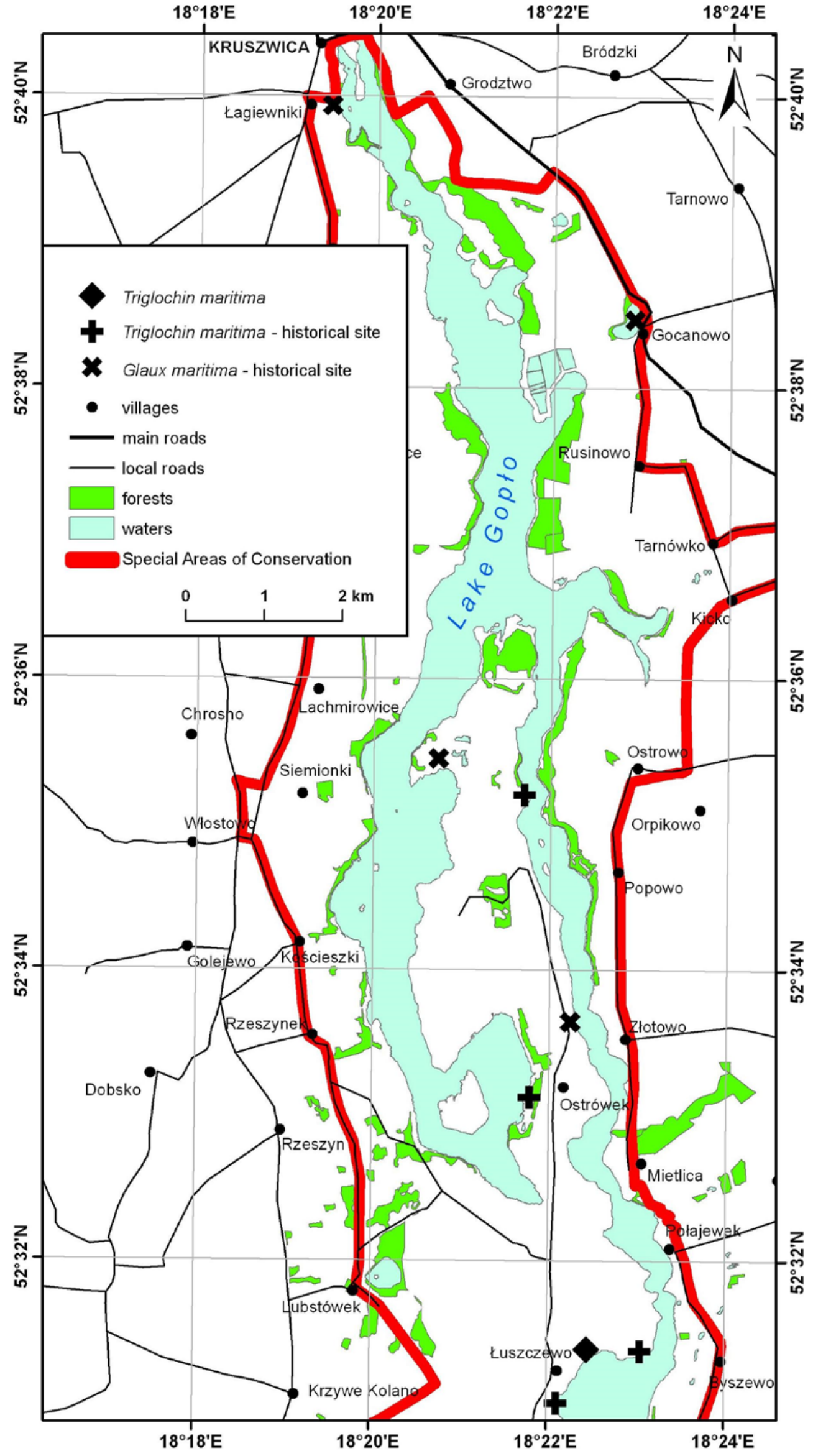

Figure 7. Occurrence of obligatory halophytes at historical and contemporary sites (2017) on plot G according to Hulisz et al. (2017a) 
Kopański only Festuca arundinacea was found. In Łuszczewo, on the other hand, the obligatory halophyte Triglochin maritima was present in the slightly halophytic association of Potentillo-Festucetum arundinaceae. In a releve made by the authors, its abundance on the Braun-Blanquet scale was assessed as 1, i.e. $<5 \%$ (numerous). This contemporary site of Triglochin maritima is located in the vicinity of two historical sites of the species (Fig. 7). In total, six out of 13 species identified in our study are included in the material describing the habitats of halophytes in the Natura 2000 Lake Gopło area.

The process of disappearance of obligatory halophytes, i.e. Glaux maritima and Triglochin maritima, observed in the area of Lake Gopło was most likely related, on the one hand, to the increase in agricultural use through fertilization, melioration, ploughing of meadows and pastures and the introduction of intensive plant varieties, and on the other hand, to the reduction or cessation of pasture use and natural succession. The cessation of use and overgrowing of meadows with reeds were, for example, the cause of the disappearance of the Glaux maritima site on the Potrzymiech Peninsula (Załuski, 1999).

The occurrence of halophytes in the area of Lake Gopło is conditioned by the presence of saline waters and soils. However, the mechanism underlying the occurrence of saline water in this area has not been clearly explained. It can be assumed that the inflow of saline water to the halophyte sites is related to the ascending movement of mineralized waters from deeper aquifers (Hulisz et al. 2017b). It is an upward movement of groundwater, often from a great depth, in a rock environment under the impact of hydrostatic pressure difference, usually through dislocation zones (Bocheńska et al., 2002). The salinity of waters may be due to their contact with deep Zechstein salt structures that commonly occur in the Kujawy region. The western part of the region is also characterized by strong dislocation, i.e. diversification of the tectonic structure of the Mesozoic substrate, which may facilitate the ascending flow of saline waters towards the ground surface. Glacial troughs and valleys, such as the glacial trough of Lake Gopło, are particularly predisposed to this type of phenomena. The research by Górski and Rosada (2008) showed that migration of saline waters towards river valleys, glacial troughs or other concave land forms is possible despite considerable distance from salt structures.

The effect of naturally saline waters on soil properties was rather insignificant at three sites monitored within the framework of habitat monitoring in the Natura 2000 PLH040007 Lake Gopło area. Only facultative halophytes were found at the site in Gocanów due to no clear effect of this factor and low soil salinity.

At the Potrzymiech site, the research showed that the level of soil salinity was similar to that of many natural inland or coastal salt marshes found in Poland (Piernik, 2012) with halophytes. According to the research, the range of soil salinity at the level of $0-25 \mathrm{~cm}$ in patches of the Festuca arundinacea and Triglochin maritima community on inland salt marshes of Central Europe is in the range of 1.53-9.26 dS m $\mathrm{m}^{-1}$. The soil at the sites on the Potrzymiech Peninsula is characterized by low natural salinity of $2-3$ $\mathrm{dS} \mathrm{m}^{-1}$ in the surface horizons, however, no obligatory halophytes (diagnostic for habitat 1340) were found there. The lack of such species can be explained by too extensive use of local meadows. The authors of the study concluded that this site is rich in eurytopic glycophyte species, which most likely prevent the development of photophilous halophytes.

In Łuszczewo, on the other hand, where the obligatory halophyte Triglochin maritima was found, the soil salinity in the patch with this species was $0.34 \mathrm{dS} \mathrm{m}^{-1}$, thus significantly lower than the lower limit of $1.53 \mathrm{dS} \mathrm{m}^{-1}$ typical of lowsalinity inland meadows in Poland. Despite such low soil salinity, Triglochin maritima is present in the meadow in Łuszczewo. Its occurrence is favored by the use of the meadow. During the research, it was found that the meadow was mown, which indicates that at low salinity, apart from adequate soil moisture, moderate use is a factor determining the duration of halophytes. Based on these observations, the authors recommended mowing the meadows twice or three times to restore and protect halophytic meadows at the sites in the area of Lake Gopło, from which the halophytes have disappeared.

The research carried out on the $\mathrm{N}$ plot showed that the intensification of the salt and soda industry contributes to the colonization of new areas by halophytes and their persistence at the existing sites. This process is closely related to the continuous flow of saline water into the soil. Almost all 90 sites included in our analysis were located in near the industrial infrastructure, i.e. saline sludge sedimentation tanks as well as saline and sewage pipelines. Due to this factor, obligatory halophytes were often present at these sites. The spread of halophytes in the area is indicated by the results of studies by Karasińska (2003), who, based on the observations carried out in 1993-1998 in an area twice as large as the one included in this study, found that at most of the 285 halophyte sites, the population resource index of 16 species was increasing. Also new localities of these species were found. The abundance of halophytes decreased only in places where the inflow of saline waters caused by anthropogenic factors was limited.

The impact of the expansion of the soda industry infrastructure on the spread of halophytes on the $\mathrm{N}$ plot can best be observed by comparing the halophyte sites along the Noteć River and the Noteć Canal in 1998 with the data provided by Professor Wilkoń-Michalska in 1957 (Wilkon- 
Michalska, 1957), when production at the soda factory in Janikowo had not yet started.

In 1953-1957, Wilkoń-Michalska (1957) observed 10 species of halophytes, including six obligatory ones (Table 3), in the Noteć valley and the Noteć Canal. The same number and the same species of halophytes were marked on the map of halophytes in the district of Inowrocław published five years later (Wilkon'-Michalska, 1963). On the other hand, Karasińska (2003), on the basis of her own research carried out in 1994-1998, found 16 species in this area. The number of obligatory halophytes (6) was the same as in 1957, but the species composition of this group of plants slightly changed. According to Wilkon-Michalska (personal communication), Aster tripolium was introduced during experiments on the growth and reproduction of halophytes on permanent plots in the vicinity of settlers of the soda factory in Mątwy. In 1998, there were 26 sites with Aster tripolium (Table 3). Over 41 years, the number of sites of other obligatory halophytes also increased: Spergularia marina three times, Salicornia europaea almost four times, Triglochin maritima and Glaux maritima two times, and Atriplex prostrata almost 30 times, from two to 59 sites. As indicated by the data in Table 3, the number of sites of all facultative halophytes, especially Puccinellia distans, also increased significantly. This table also provides the number of Festuca arundinacea sites, an facultative halophyte species not included in the study by Wilkon'-Michalska (1957).

Table 3. The number of halophyte sites along the Noteć River and the Noteć Canal in 1957 and 1998 according to Wilkoń-Michalska (1957) and Karasińska (2003)

\begin{tabular}{|c|c|c|c|}
\hline \multirow{2}{*}{ No. } & \multirow{2}{*}{ Species } & \multicolumn{2}{|c|}{ Number of sites in year } \\
\hline & & 1957 & 1998 \\
\hline 1. & ${ }^{*}$ Spergularia marina (L.) Besser & 17 & 51 \\
\hline 2. & ${ }^{*}$ Salicornia europaea L. & 11 & 40 \\
\hline 3. & ${ }^{*}$ Triglochin maritima $\mathrm{L}$. & 12 & 25 \\
\hline 4. & ${ }^{*}$ Glaux maritima $\mathrm{L}$. & 5 & 11 \\
\hline 5. & ${ }^{*}$ Atriplex prostrata Boucher ex DC & 2 & 59 \\
\hline 6. & ${ }^{*}$ Aster tripolium $\mathrm{L}$. & 0 & 26 \\
\hline 7. & ${ }^{*}$ Juncus gerardi Loisel. & 4 & 0 \\
\hline 8. & Puccinellia distans (Jacq.) Parl. & 17 & 96 \\
\hline 9. & Trifolium fragiferum $\mathrm{L}$. & 8 & 30 \\
\hline 10. & Lotus maritimus L. & 6 & 41 \\
\hline 11. & Festuca arundinacea Schreb. & $?$ & 11 \\
\hline 12. & Lotus tenuis Waldst. \& Kit. & 7 & 4 \\
\hline 13. & Bolboschoenus maritimus (L.) Palla & 0 & 27 \\
\hline 14. & $\begin{array}{l}\text { Schoenoplectus tabernaemontani } \\
\text { (C.C. Gmel.) Palla }\end{array}$ & 0 & 16 \\
\hline 15. & Carex distans $\mathrm{L}$. & 0 & 5 \\
\hline 16. & $\begin{array}{l}\text { Melilotus dentatus (Waldst. \& Kit.) } \\
\text { Pers. }\end{array}$ & 0 & 3 \\
\hline 17. & Althaea officinalis $\mathrm{L}$. & 0 & 2 \\
\hline
\end{tabular}

*obligatory halophytes
The spatial distribution of sites with halophytes growing in places with the highest soil salinity (i.e. Salicornia europaea) in 1957 and 1998 is shown in Figures 8A and 8B, while the occurrence of Aster tripolium in 1998 on the $\mathrm{N}$ plot (as it was not recorded on this plot in 1957) is presented in Figure 9.

An important role in the formation of salt marshes is played by settlers of saline lime sludge, and the spread of halophytes is favored by the existence of the Noteć Canal. When analysing the role of these factors in the vicinity of the soda factory in Mątwy, Wilkon'-Michalska (1963) stated that "the largest concentrations of halophytes are observed in the factory area, i.e. in the vicinity of the so-called white sea, i.e. huge heaps of saline lime sludge, and between the factory and the Noteć Canal. The influence of the soda factory, however, is not limited to its immediate vicinity, but extends to further areas, because by-products formed during the production of soda and containing large amounts of chlorides are discharged into the Noteć River". And she further writes: "halophytes spread along the Noteć River mainly due to saline alluvium from dredging the river and due to river flooding".

The abundant occurrence of halophytes on the G plot is determined by the continuous inflow of saline water to the soil. The intensification of industrial production, which continued from the 1950s to the late 20th century, increased the migration of saline water and chloride ions contained in that water in the vicinity of soda factories, and thus increased the number of sites with halophytes and their population resources in the study area. In consideration of the resulting environmental hazards at the turn of the 20th and 21st centuries, both soda plants undertook measures to reduce the environmental impact of industrial production. These measures include sealing the bottom of settling tanks, building sewage clarifiers, introducing a closed cooling water cycle, a drain collecting saline groundwater, reducing the amount of waste at the "Janikosoda SA" factory, and using a pro-ecological heavy soda production technology purchased in France and Germany, creating a gravitational barrier around settling tanks, washing, sorting and recycling waste in the plants of "Soda Mątwy SA". The aforementioned measures may contribute to the reduction of soil salinity and the decline in population resources or even the disappearance of some species of halophytes occurring in salt marshes developed under anthropopressure. Such a scenario of changes in environmental conditions, considered very likely, results from prognostic hydrogeological models developed for the areas around the soda plants (Sukowski \& Polańska, 2000, 2001). Further monitoring of the halophytes along the Noteć Canal will provide an answer to the question whether the direction of changes presented in the tables and on the map produced in our study will be maintained or reversed. 

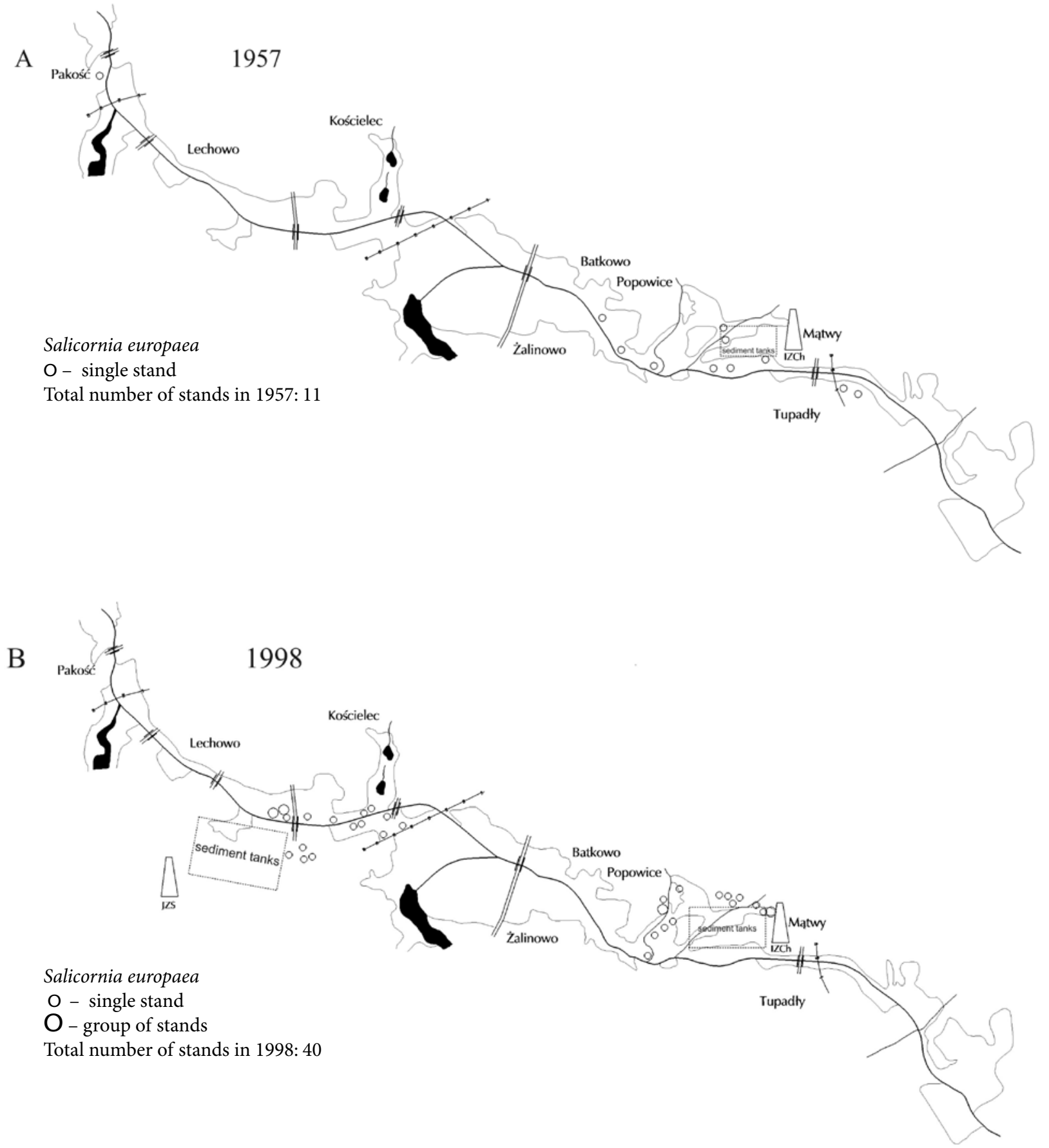

Figure 8. Distribution of Salicornia europaea along the Noteć River and the Noteć Canal in 1957 (A) and 1998 (B) according to Wilkoń-Michalska (1957) and Karasińska (2003) 


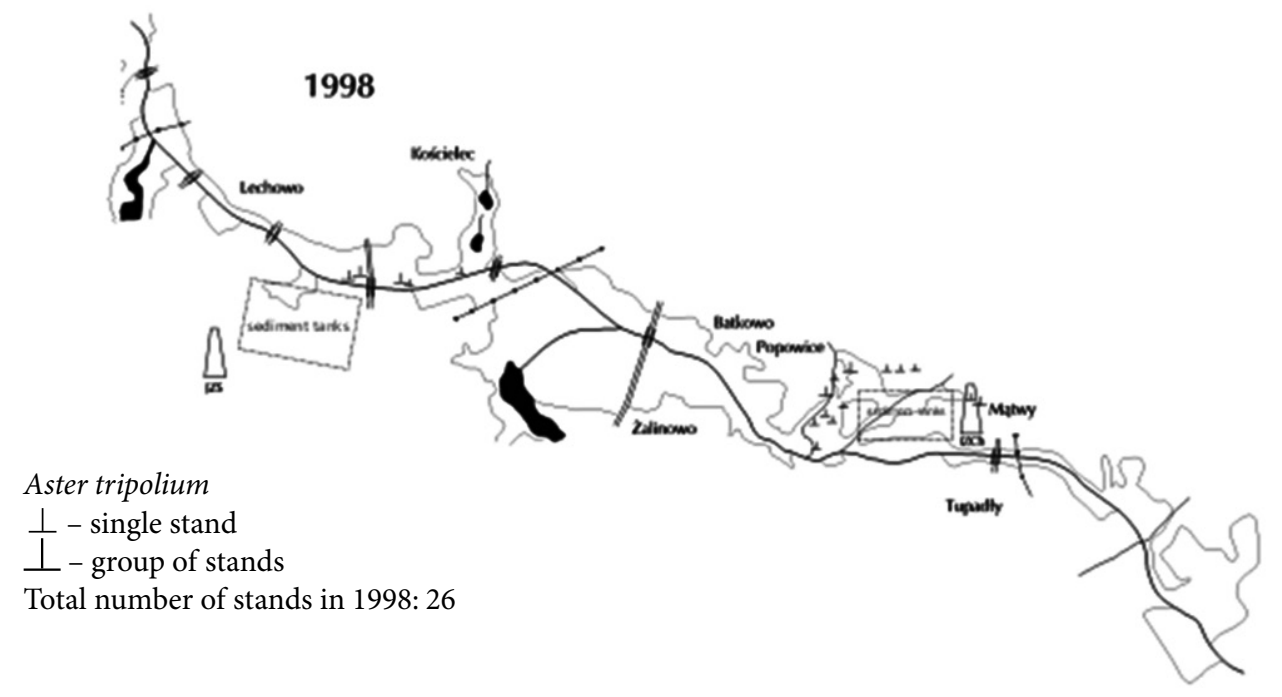

Figure 9. Distribution of Aster tripolium along the Noteć River and the Noteć Canal in 1998 according to Karasińska (2003)

\section{Conclusions}

1. The flora of halophytes on two plots under different types of anthropopressure significantly differs. In the area with natural soil salinity caused by groundwater, mainly facultative halophytes occur, while obligatory halophytes occur only sporadically. On the other hand, in the area with a strong saline water inflow generated by economic activity, the flora of halophytes is much richer, especially in obligatory species, and their population resources are very high.

2. In naturally saline meadows, where soil salinity is low, competition from tall perennials is an important factor limiting the development of halophytes. In order to preserve these rare plant species, it is important to undertake active protection through the use of such treatments as grazing and mowing.

3. Technological changes introduced in recent years by the Mątwy and Janikowo plants in soda production technology and waste management will result in a reduction of population resources, and most likely a decline in the species richness of halophytes in the vicinity of the Noteć Canal.

4. Tables and cartographic materials prepared as part of this work may serve as a reference for assessing the extent of floristic changes in both study areas in the future, and thus for assessing the effects of active protection, the introduction of environmentally friendly technologies in agriculture and industry, and for verifying the validity of the developed scenarios and forecasting models.

\section{References}

Abromeit J., Jentzsch A., Neuhoff W., Steffen H. \& Vogel G, 1898-1940, Flora von Ost- und Westpreussen heransgegeben vom Preussischen Botanischen Verein zu Königsberg (Pr). Kommissionsverlag Gräfe und Unzer, Königsberg (Pr).

Bank Ch. \& Spitzenberg D. (eds.)., 2001. Darstellung der derzeit. Die Salzstelle Hecklingen bedeutendsten Binnenlandsalzstellen in Deutschland. Hereausgegeben von der Fachgruppe Faunistik und Ökologie, Stassfurt.

Bock W., 1908, Tachenflora von Bromberg (des Netzegebiete). Bromberg.

Bocheńska T., Dowgiałło J., Kleczkowski A., Krajewski S., Maciaszczyk T., Małecka D., Rogoż M., Różkowski A., Szczepański A. \& Witczak S., 2002, Słownik hydrogeologiczny [Hydrogeological dictionary]. PIG, Warszawa.

Chmiel J., 1987, Nowe i rzadsze gatunki we florze wschodniej części Pojezierza Gnieźnieńskiego. Część 2. Bad. Fizjogr. nad Polską Zach. Ser. B, 38: 67-79.

Chmiel J., 1999. 4 Operat ochrony flory, [in:] M. Przewoźniak (ed.) Plan ochrony Nadgoplańskiego Parku Tysiąclecia. Etap 2 Operaty szczegółowe. Proeko, Biuro Projektów i Wdrożeń Proekologicznych, Poznań-Gdańsk. 
Choiński A., 2006, Katalog jezior Polski [Catalogue of Polish lakes]. Wydawnictwo UAM, Poznań.

Decyzja Komisji z dnia 12 grudnia 2008 r. przyjmująca na mocy dyrektywy Rady 92/43/EWG drugi zaktualizowany wykaz terenów mających znaczenie dla Wspólnoty składających się na kontynentalny region biogeograficzny (notyfikowana jako dokument nr C(2008) 8039) (2009/93/WE). Dziennik Urzędowy Unii Europejskiej, L 43/63 [Commission Decision of 12 December 2008 adopting, pursuant to Council Directive 92/43/EEC, a second updated list of sites of Community importance for the Continental biogeographical region (notified under document number C(2008) 8039). Official Journal of the European Union, L 43/63].

Dorożyński R. \& Skowron R., 2002, Changes of the basin of Lake Gopło caused by melioration work in the 18th and 19th centuries. Limnol. Rev. 2: 93-102.

Górski J. \& Rosada M., 2008, Hydrogeologia wybranych wysadów solnych regionu kujawskiego - aspekty poznawcze i utylitarne. Geologos vol. 13. Monographiae 5. Bogucki Wyd. Naukowe, Poznań.

Grabarek B., 1974,Z dziejów kopalnictwa soli w Inowrocławiu od XIX do drugiej połowy XX wieku. Ziemia Kujawska 4: 57-75.

Hill M.O., 1979, TWINSPAN: A FORTRAN Program for Arranging Multivariate Data in an Ordered Two-way Table by Classification of the Individuals and Attributes. Ecology and Systematics, Cornell University, Ithaca, New York 14850, $90 \mathrm{pp}$.

Hulisz P., Krawiec A., Piernik A. \& Kamiński D., 2017a, Ekspertyza w zakresie możliwości utrzymania siedlisk halofitów w obszarze Natura 2000 Jezioro Gopło PLH04007. UMK, Toruń. [wykonana na zlecenie Regionalnej Dyrekcji Ochrony Środowiska w Bydgoszczy, Dofinansowano ze środków Wojewódzkiego Funduszu Ochrony Środowiska i Gospodarki Wodnej w Toruniu].

Hulisz P., Krawiec A., Pindral S., Mendyk Ł. \& Pawlikowska K., 2017b, The impact of environmental conditions on water salinity in the area of the city Inowrocław (north-central Poland). Bulletin of Geography. Physical Geography Series 13(1): 5-15.

KarasińskaW.,2003 mscr.Halofity siedlisk antropogenicznych zachodniej części Kujaw. Praca doktorska [Halophytes of anthropogenic habitats in the western part of Kujawy. $\mathrm{PhD}$ Thesis]. Pracownia Modelowania Procesów Ekologicznych, UMK, Toruń.

Kondracki J., 2000. Geografia fizyczna Polski [Physical geography of Poland]. Wydawnictwo Naukowe PWN, Warszawa.

Kovach W.L., 1993, A MultiVariate Statistical Package for OBM-PC's ver. 2.1. Kovach Computing Services, Pentraech, Wales, U.K.
Kozłowski S., Leszczyszyn H. \& Kossakowska E., 1989, Regionalizacja eksploatacji surowców mineralnych na tle warunków środowiskowych, mapa 1:500 000. Państwowy Instytut Geologiczny, Warszawa.

Liebetanz B., 1925, Hydrobiologische Studien an Kujawischen Brackwässern. Bull. de l'Ac. Pol. des Sc. et des Lettr. Cl. des Sc. Math. Natur. Ser. B.

Marszelewski W. \& Skowron R., 2011, Związki między odwodnieniem odkrywki Tomisławice a wybranymi elementami ustroju hydrologicznego jeziora Gopło. [Relations between dewatering of the Tomislawice open-pit mine and selected elements of the Lake Goplo hydrological regime]. Rocz. Glebozn. 62(2): 273-282.

Mastyński Z. \& Rogiński S., 1964, Studium historycznohydrologiczne jeziora Gopła. Prace Wydziału Nauk Przyrodniczych Bydgoskiego Towarzystwa Naukowego, Seria B, No. 3, Bydgoszcz.

Matuszkiewicz J.M., 1993. Krajobrazy roślinne i regiony geobotaniczne Polski. Prace Geogr. [Vegetation landscape and geobotanical regions of Poland. Geographical Studies] 59: 321-349.

Mirek Z., Piękoś-Mirkowa H., Zając A. \& Zając M., 2002, Flowering Plants and Pteridophytes of Poland. A checklist. W. Szafer Institute of Botany, Polish Academy of Sciences, Kraków.

Nienartowicz A. \& Piernik A., 2004, * Śródlądowe błotniste solniska z solirodem (Salicornion ramosissimae), p. 76-82, [in:] J. Herbich (ed.), Podręczniki ochrony siedlisk i gatunków Natura 2000. Siedliska morskie i przybrzeżne, nadmorskie i śródlądowe solniska i wydm. Ministerstwo Środowiska, Unia Europejska, Warszawa.

Nienartowicz A. \& Warot L., 2001, Ochrona halofitów na Kujawach a zrównoważony rozwój [Protection of halophytes and sustainable development in Kujawy region]. Przegląd Przyrodniczy, Wyd. Lubuski Klub Przyr., Świebodzin, XII(3-4): 205-214.

Nienartowicz A. \& Wilkoń-Michalska J., 1993a. The application of numerical analysis to comparison of ecological amplitudes of halophytic species. Variability and Evolution 2/3: 103-112.

Nienartowicz A. \& Wilkoń-Michalska J., 1993b, Numerical syntaxonomy of the Polish halophilous plant communities. Pol. Bot. Stud. 5: 61-69.

Niewiarowski W., 2000, Uwagi o wahaniach poziomu wody w jeziorze Gopło: stanowisko 3 - Kruszwica (gm. Kruszwica), [in:] P. Molewski, W. Wysota (eds.), Dawne i współczesne systemy morfogenetyczne środkowej części Polski Północnej: przewodnik wycieczek terenowych, V Zjazd Geomorfologów Polskich, Toruń 11-14 września $2000 \mathrm{r}$. [The former and contemporary morphogenetic systems of central part of the North Poland, V Congres 
of the Association of Polish Geomorphologists: Guide of excursions, Toruń 11-14 September 2000], p. 189-194. Wyd. UMK, Torun.

Papierowski Z., 1963, Inowrocław Zdrój. Kujawskie zdrojowisko solankowo-borowinowe w świetle badań naukowych. PZWL, Warszawa.

Piernik A., 2000 mscr. Halofity jako indykatory zasolenia podłoża na Kujawach. Praca doktorska [Halophytes as indicators of soil salinity in Kujawy. PhD Thesis]. Pracownia Modelowania Procesów Ekologicznych, UMK, Toruń.

Piernik A., 2003a. Inland halophilous vegetation as indicator of soil salinity. Basic and Applied Ecology 4: 525-536.

Piernik A., 2003b. Three types of gradients in the saline ecosystem. Ecological Questions 3: 85-92.

Piernik A., 2012, Ecological pattern of inland salt-marsh vegetation in central Europe. Wyd. Naukowe UMK, Toruń.

Pusch J., 2007. Die naturnahen Binnensalzstellen Thüringens - ein aktueller Gesamtüberblick des Jahres 2005. In: Thüringer Ministerium für Landwirtschaft, Naturschutzund Umwelt (ed.). Die Binnensalzstellen Mitteleuropas: 37-40.

Rostafiński J., 1871, Florae Polonicae Prodromus, p. 82-208. Zool.-Bot. Ges., Österreich, Austria.

Rozporządzenie Ministra Środowiska z dnia 21.07.2004 r. w sprawie obszarów specjalnej ochrony ptaków Natura 2000 (Dz. U. z dnia 21 października 2004 r.) [Regulation of the Minister of the Environment of 21 July 2004 on special protection areas for birds (Dz.U. 21 October 2004)]. Dz.U.04.229.2313.

Schmeisky H. \& Podlacha G., 2000. Natural revegetation of saline waste dumps - drought tolerant specialists and halophytes. Landscape and Urban Planning 51: 159-163.

Sikorski Cz., 1988, Miasto na soli. Zarys historii Inowrocławia do roku 1919, Wyd. Spółdzielcze. Warszawa.

Spribille F., 1889, Nachträge zum Verzeichnisse der in den Kreisen Inowrazlaw und Strelno bisher beobachteten Gefässpflanzen mit Standortsangaben. Wissenschaftliche Beilage des Programms Osten. Programm 144.

Sukowski T. \& Polańska K., 2000, Ochrona wód podziemnych w rejonie Janikowa. Sprawozdanie za rok 1999. Pracownia Modelowania Hydrogeologicznego, Gdańsk.

Sukowski T. \& Polańska K., 2001, Ochrona wód podziemnych w rejonie Janikowa. Sprawozdanie za rok 2000. Pracownia Modelowania Hydrogeologicznego, Gdańsk.

Szafer W. \& Zarzycki K. (eds.), 1972, Szata roślinna Polski [The vegetation of Poland]. PWN, Warszawa.

Trzcińska-Tacik H., 1988. Halofity nad dolną Nidą [Halophytes on the Lower Nida River]. Zeszyty Naukowe Uniwersytetu Jagiellońskiego, DCCCLXXII, Prace Botaniczne 17: 133-154.
Twerd L., 2012, Tendencje dynamiczne halofitów Kujaw. Wydawnictwo Uniwersytetu Kazimierza Wielkiego, Bydgoszcz.

van Elsen T., 2005. Das Potenzial primärer und sekundärer Binnensalzstellen in Türingen für den Naturschutz - Zur Vegetation der Salzwiesen im Esperstedter Ried und an Kali-Rückstandshalden, [in:] Thüringer Ministerium für Landwirtschaft, Naturschutzund Umwelt (ed.). Die Binnensalzstellen Mitteleuropas: 71-85.

Warot L., 2003 mscr. Historyczne i współczesne tendencje rozwojowe halofitów na stanowiskach śródlądowych. Praca doktorska [Historical and contemporary trends in the development of halophytes at inland sites. $\mathrm{PhD}$ Thesis]. Pracownia Modelowania Procesów Ekologicznych, UMK, Toruń.

Warot L., Nienartowicz A. \& Załuski T., 2001. System informacji o występowaniu halofitów na Kujawach [Information system: Distribution of halophytes in Kujawy], [in:] A. Nienartowicz, M. Kunz (eds.) GIS i teledetekcja w badaniach struktury i funkcjonowania krajobrazu GIS and Remote Sensing in studies of landscape structure and functioning], p. 241-249. O.W. TURPRESS, Toruń.

Westhus W., Fritzlar F., Pusch J., van Elsen T., Andres C., Grossmann M., Pfützenreuter S., Sparmberg H. \& Barthel K. J., 1997. Binnensalzstellen in Türingen - Situation, Gefährdung und Schutz. Naturschutz report, Heft 12, Jena.

WFO, 2021, World Flora Online. Published on the Internet. http://www.worldfloraonline.org [Accessed on: 30 May 2021]

Wilkoń-Michalska J., 1957. Łąki zasolone w dolinie Noteci na odcinku Mątwy-Nakło [Saline Meadows in the Noteć River Valley]. Rocz. Nauk Roln., Ser. F-2, 72: 893-920.

Wilkoń-Michalska J., 1962. Rezerwat halofitów w Ciechocinku i jego znaczenie [Reserve of halophytes in the town of Ciechocinek and its importance]. Chrońmy Przyrodę Ojczystą 18: 6-17.

Wilkoń-Michalska J., 1963. Halofity Kujaw [The halophytes from Kujawy]. Stud. Soc. Sci. Torun., Sec. D (Botanica) 7, 1: 1-222.

Wilkoń-Michalska J., 1970.Zmiany sukcesyjne w rezerwacie halofitów w Ciechocinku w latach 1954-65 [The succesion changes in the reserve of halophytes in Ciechocinek in years 1954-65]. Ochrona Przyrody 35: 25-51.

Wilkoń-Michalska J., 1986. Tendencje rozwojowe i ochrona halofitów w Polsce [Development tendencies and protection of halophytes in Poland]. Acta Universitatis Łodziensis B: 123-129.

Wilkoń-Michalska J., Nienartowicz A. \& Piernik A., 1997. Struktura i funkcjonowanie ekosystemów solniskowych na Kujawach [The structure and functioning of salt marsh 
ecosystems in the Kujawy region], [in:] W. Fałtynowicz, M. Latałowa, J. Szmeja (eds.) Dynamika i ochrona roślinności Pomorza [Dynamics and Protection of Vegetation in Pomerania], p. 65-72. Bogucki Wyd. Nauk., Gdańsk-Poznań.

Wodziczko A., Krawiec F., \& Urbański J., 1938, Pomniki i zabytki przyrody Wielkopolski. Wyd. Okr. Kom. Ochr. Przyr. na Wielkopolskę i Pomorze 8: 313-360, Poznań.

Załuski T., 1992 mscr., Materiały do rozmieszczenia rzadkich i chronionych gatunków roślin (z uwzględnieniem halo- fitów) na terenie Nadgoplańskiego Parku Tysiąclecia. Dyrekcja NPT, Kruszwica.

Załuski T., 1995, Materiały do flory Kujaw. Acta Univ. Nicolai Copernici, Nauki Mat.-Przyr. 93, Biologia 48: 185-189.

Załuski T., 1999, 3 Operat ochrony szaty roślinnej, [in:] M. Przewoźniak (ed.), Plan ochrony Nadgoplańskiego Parku Tysiąclecia. Etap 2 Operaty szczegółowe. Proeko, Biuro Projektów i Wdrożeń Proekologicznych, Toruń-Gdańsk. 